\title{
How Der Sklavenkrieg became The Gladiators: Reflections on Edith Simon's translation of Arthur Koestler's novel
}

The problems facing German writers in securing publication in Britain were further exacerbated by the dearth of outstanding translators. In compiling a list of literary translators from German, the two couples Edwin and Willa Muir, and Eden and Cedar Paul, spring immediately to mind, followed perhaps by the names of Eric Sutton [...] and A.H. Wheen. However, apart from these it is hard to think of any other well-known translators from

German. Translation may sometimes have been a labour of love. More often it was jobbing-work: badly paid and poorly regarded. Many of those responsible for the translation of German books in the twenties and thirties translated only one, or at most two, works.

(Dove, 2000: 42-43)

\author{
HENRY INNES MACADAM* \\ DeVry University
}

Received: 16/05/2016. Accepted: 30/11/2016.

\begin{abstract}
All German original manuscripts of Arthur Koestler's first two novels (The Gladiators and Darkness at noon) were lost during World War II. A MS of each was recently recovered, allowing for the first time a comparison with their initial English translations, for almost 80 years the basis of all other translations. Both novels will be published in German and in a new English translation that allows comparison with the original English editions. This article provides context for the first translation of Der Sklavenkrieg by Edith Simon (1917-2003), through correspondence with Simon's younger sister Inge Simon Goodwin (1923-2014), and Simon's daughter, Antonia Reeve. It also briefly addresses some editorial changes in the table of contents for The Gladiators, anomalies within Simon's rendition of descriptive prose, and an example of Simon's skills as translator of Koestler's imaginative prose. These are preliminary observations only, in anticipation of the novel's retranslation and republication in 2018 .
\end{abstract}

KEYWORDS: Arthur Koestler, Der Sklavenkrieg, Matthias Wessel, Michael Scammell, Edith Simon, The Gladiators, Inge Simon Goodwin, translation examples, correspondence.

*Address for correspondence: Henry Innes MacAdam. Liberal Arts \& Sciences Department, DeVry University, North Brunswick, NJ, United States; e-mail: HMacadam@devry.edu. 


\section{INTRODUCTION}

This article evolved from transcripts of correspondence to me, and from commentary on those letters by me, that I shared with Matthias Wessel in late 2015. He was then a German doctoral candidate in the final stages of research for a dissertation on "Arthur Koestler's Novels in Exile", for submission to the University of Kassel in December 2017. Wessel's focus is the three novels Koestler wrote during the decade after Nazi ascendancy in 1933: The Gladiators (1965), Darkness at noon (1973), and Arrival and departure (1966). ${ }^{1}$ All three are devoted to what Koestler termed a study through fiction of "ends and means", or what he collectively called the Law of detours: "[Their common] theme is the conflict between morality and expediency" (Koestler, 1966: 190). Arrival and departure was written in English, his language of choice for the rest of his writing career. ${ }^{2}$

Wessel was making plans to visit Moscow in the aftermath of his discovery in Zurich of the German original typescript of Koestler's best-known and most influential novel, Darkness at noon. ${ }^{3}$ Wessel has since generously shared information about this discovery with Michael Scammell, who engaged a far larger readership than just an academic website through his essay "A different Darkness at noon" (2016). Scammell had seen Der Sklavenkrieg among Koestler's papers during a research visit to the former KGB archives in the early 1990s (Scammell, 2009: 164 and note \# 1). These had been confiscated from Koestler's apartment in Paris in 1940, taken to Berlin soon afterward, and eventually brought to Moscow at the end of World War II (hereafter, WW II). Scammell used his essay on Darkness at noon to announce Wessel's plans to study the Koestler papers in Moscow, with a focus on the German original manuscript (MS) of The Gladiators.

Thus we may anticipate the eventual publication of both novels as they were envisioned when Koestler brought them to completion as WW II began to engulf all of Western Europe by 1940. Darkness at noon is considered Koestler's literary masterpiece, but Scammell demonstrates clearly that the English translation done by Daphne Hardy can now be judged inadequate. The same may not be true of Edith Simon's translation of The Gladiators. Below I first reconstruct the translation procedure of the latter as I learned about it through contact with Simon's sister Inge and daughter Antonia Reeve. Then I draw attention to some problematical word choices by Simon in an early passage of the novel. Lastly I point to editorial changes in the layout of the novel, and give an example of Simon's masterful rendition of Koestler's imagery and character study toward the end of the novel. These analyses are possible thanks to notes made by Wessel which he shared with me. Readers must be aware that what I offer is only a restricted case study prior to Wessel's full publication of the original text. 


\section{BACKGROUND: SELLING A NOVEL IN TRANSLATION}

\subsection{A novel for sale}

Sometime during mid-summer of 1938, the 32 year-old Arthur Koestler brought to London the completed German typescript of his first novel to be published. He had entitled it Der Sklavenkrieg (The slave war). Details of how he made contact with Edith Simon, the young (21) German immigrant woman whom he hired to translate it, are not at all clear. Koestler himself was quite opaque about this in the second volume of his autobiography (The invisible writing). At the end of Chapter 24, entitled "An Excursus into the First Century BC", his account of researching and writing it ends with this afterthought: "The novel was first published in England in [March] 1939, in an excellent translation by Edith Simon. Then the war broke out, the German manuscript was lost during my flight from France [in the spring of 1940], and the [West] German edition which appeared after the war [1948] had to be retranslated from the English translation. A similar misfortune befell the next novel, Darkness at noon [which was back-translated into German in 1946]" (Koestler, 1969: 327).

Later in that same volume he reaches 1938 in his chronological narrative:

When I returned to Paris [from London] in the beginning of 1938 I had brought with me a precious document. It was an agreement with Jonathan Cape in London for the publication of The Gladiators, my first novel to appear in print. Cape had paid me an advance of, I believe, a hundred and twenty-five pounds; though I had to pay the cost of translation, it left me with just enough for six months of Spartan living. Thus I was at last able to finish this book which I had been forced to abandon time and again, either because I had run out of money or under pressure of political events. I finished it in July 1938, four years after I began it.

After each of these more or less dramatic interruptions, the return to the first century $\mathrm{BC}$ had filled me with peace and relief. During the months before and after the break with the Party, it became an occupational therapy. It gave me a sense of continuity which tided me over that period of outer loneliness and inner emptiness. Before the break, I had thought of myself as a servant of the Cause, and of writing as a means of serving it. Now I began to regard myself as a professional writer, and writing as a purpose in itself. As soon as I had finished The Gladiators, I began to write Darkness at Noon (Koestler, 1969: 478-479).

We are left to fill in the blanks regarding the novel's publication process, notably the translation and any editorial changes that followed. Luckily we know something about the background of Edith Simon (1917-2003), already a published writer and talented art student hired for that task. ${ }^{4}$ Many German-Jewish individuals and families had left Nazi-controlled Germany after the elections of late 1932 and the subsequent accession of Hitler as Chancellor at the end of January 1933. The Simon family (parents and two daughters) anticipated that 
transition and left before the elections. Koestler must have made contact with Edith through friends of his who knew her, either directly or indirectly, during one of several visits to London following his release from imprisonment and near-execution in Spain in early 1937, and the subsequent publication (in London) of his account of that in Spanish testament (December 1937).

He may have concluded that the translators he had hired for that non-fiction, journalistic work would not be up to the task of rendering his novel into English (Scammell, 2009: 145, 148). If so, it may have been for no other reason than this was Koestler's first attempt to publish a historical novel - and he probably knew (or at least his editor did) that novels about past events were selling far better than those featuring contemporary European settings and situations: "The historical novel was a positive genre with a broad reading public [in the UK] largely uninterested in contemporary events in [1930s] Europe. It was one adopted by a number of exiled writers, since it allied an appeal to popular taste with the opportunity to present contemporary political questions through the device of historical distance" (Dove, 2000: 67). Simon's sister Inge, who turned 15 years old in late 1938, remembers only that Edith had been "commissioned to translate" Der Sklavenkrieg (Goodwin, 2005: 7) and was paid by Koestler, not by Cape.

Koestler undoubtedly knew about the very recent success of the Austrian-Jewish voluntary exile Stefan Zweig in publishing historical non-fiction in the UK. Zweig's biography of Mary Stuart (The Queen of Scots, 1935) had become an international best-seller through its English translation. But Zweig, although no longer able to publish in Nazi Germany and Austria, was a global literary figure before the Hitler era began (Dove, 2000: 43-63). Koestler by contrast was almost unknown in the Anglophone world except as an antifascist journalist. His own great skill in writing biographies of major European scientific figures (Copernicus, Kepler, Galileo, Newton) still lay several decades in the future (The sleepwalkers, 1959). Much closer to Koestler in age, and more similar in circumstances, was another Austrian-Jewish exile in London, Robert Neumann.

Neumann fled Nazi Germany in 1933, and then left Austria after the Anschluss three years later. He was relatively unknown outside Germany and the Germanophone countries, and needed translation into English as an entrée to the UK publishing scene. He succeeded in publishing a historical novel (The Queen's doctor, 1936) of dubious literary merit, and might have had an original screenplay filmed if the British movie industry had not imploded during the Great Depression (Dove, 2000: 63-73). Both men began to write in English during WW II. After the war, Koestler would option two of his own novels (Darkness at noon and The Gladiators), only to see neither of them filmed for differing reasons. Those parallels between the careers of Neumann and Koestler as German-speaking exile writers within wartime Britain have been examined very recently (Wessel, 2014).

1938 became the "breakthrough" year for Koestler. On the popular strength of his recently published Spanish testament he had secured a book contract with Cape. Some 
aspects of that are discussed in section 2.4 below. His next challenge was to find a competent translator, and the last hurdle would be having the translated novel recommended by Cape's "publisher's reader" and then steered through the publication process by someone at Cape who championed his cause. As it happened, just such a person had begun working there the previous year. ${ }^{5}$ But we must first piece together the translation process.

\subsection{Koestler's German translator}

Koestler's contact with Edith Simon is sketched in several other publications (MacAdam, 2006: 69-71; Simon, 2009: 113, 136-137; Simon, 2011: 43-44), but it may help Koestler scholars if we enlarge upon here what was only mentioned in passing there. The additional information comes through contact with Edith Simon's younger sister Inge Simon Goodwin (1923-2014) and Edith's daughter Antonia Reeve. This consists of letters and e-mail messages between 2005 and the present. ${ }^{6}$ Contact with Antonia Reeve was made when this email message arrived:

\section{Dear Sir:}

I am Edith Simon's daughter, and my father Dr. E.C.R. Reeve is still very much alive. Your timing is very good, as I have just published a book on Edith [...] One of the sections is written by Edith's sister Inge Goodwin, and the whole book gives a very good idea of Edith and what she did with her life. I will check, but I don't think the German typescript [of Der Sklavenkrieg] is among her papers. She published 17 books and wrote plays and film scripts before changing to Art, so there is a lot of her own material. Yours, Antonia Reeve.

Without confirmation that the MS had been saved by Simon, the search for it seemed at a dead end. The only other known copy of Der Sklavenkrieg was among Koestler's personal papers confiscated by the French anti-communist police (Deuxième Bureau) in September 1939 (Koestler, 1969: 489). Certainty that it was not in Simon's papers came in a follow-up e-mail of 30 August 2005, in which Antonia Reeve added relevant information that her aunt Inge had provided: "Edith did the translation in a tiny corner of her tiny bedroom, and it was typed up by her sister Inge, so she [Inge] would be able to give you more details [...] Edith did at least one other [translation and/or transcribing] project with Koestler. We have failed to find the [German] manuscript [of Der Sklavenkrieg]; she can't have kept it, or at any rate didn't bring it up to Edinburgh when she moved up here [after WW II]".

Two days later more details emerged of that period in Edith's life in another e-mail from Antonia Reeve, creating a small contradiction regarding the translation of The Gladiators: 
[It is] fascinating [to learn from you] that the German [of a later edition of The Gladiators] is from Edith's [English] translation! Edith discussed the translation [with Inge] as she went, although it seems Edith typed The Gladiators herself; it was later stuff [for Koestler] that Inge typed. Edith was pretty extraordinary. She published her first novel [The chosen, 1940] at age 23, in English, having only arrived in England [1932] at age 15 (and returning to Berlin for a year to finish her education there [i.e. Reifezeugnis or Certificate of Maturity $=$ British O-levels], going to art college (and dropping out) and being involved with the beginning of the Artists International Association in 1933. She didn't fully turn to writing till later (although always having written things). In 1937 she published a children's book [Somersaults and Strange Company] and then was writing her first novel and translating The Gladiators at the same time! Edith was in London at that time and met with Koestler there [...] Inge says there were other bits of books including an encyclopedia of sex knowledge published by Koestler's cousin Francis Aldor, [for] which Edith and Inge had some input [...] I don't know how Koestler heard of Edith-I'll try to find out.

It would make more sense that Inge typed the translation of The Gladiators as Edith read aloud her rendering of the German typescript. If Edith had typed the novel as she sighttranslated from Koestler's typescript there would have been no need for Inge to assist. But a later letter from Inge (see below) describes their work together on the sex manual, and it seems clear from her account that it was her [Inge's] first typing assignment. In early 2006 Inge was directly contacted by post at her London address, and was asked if she recognized the cover art on the USA first edition of The Gladiators as Edith's, and about her personal recollection of Koestler and Francis Aldor. Her handwritten response is dated 20 March 2006:

One or two points [of your letter] I can answer quite quickly. The beautiful cover to the American edition of The Gladiators which you [photocopied and] sent: I have no feeling of recognition regarding it. I think it unlikely that Edith did it, but have no certainty either way.

Ferenc (Francis) Aldor I only met about twice. Edith got me the job of typing the MS of "The Practice of Sex" (a much shorter book than the "Encyclopedia of Sexual Knowledge"). I was about 16, and learnt to type on this assignment. When, accompanied by my guardian-angel sister, I delivered this typescript-quite a hefty pile-Aldor switched his green eyes on me and demanded of Edith: "You allowed this pure innocent child to type this?" Both of us happily assented, and I collected my not very generous earnings (it was, however, my first-ever earnings).

Aldor, though he had green eyes and black hair, was no beauty. He was small and stocky, with a square face. [Christopher] Isherwood, in Prater Violet, speaks of "the face of Central Europe." "7 Aldor had the confident air of someone magnetic and irresistible. As did Koestler, of course, according to E[dith]. But in Koestler's case there was also the 
wit and intelligence: he really was hard to resist, by all accounts a very successful and entertaining predator.

Several months later Inge was sent a copy of the article about Koestler and The Gladiators (MacAdam, 2006), and she wrote a month later (7 July 2006) to remind me that she had not forgotten an earlier request for more information about Koestler and Edith: "I am writing you a longer letter to address some of your points and answer some of your questions". It was not until 7 February 2007 that the promised letter arrived, and it began where she had left off almost a year earlier:

I hope I have not failed to give the impression that Edith had the greatest respect and admiration for Koestler as a writer and thinker, which made translating The Gladiators such an absorbing and satisfying task. The predatory side of him is well documented by other women, notably Michael Foote's late wife Jill Craigie, who did not enjoy her acquaintance with Koestler as much as Edith did [...]

[...] I must have seen the German original typescript of The Gladiators, but cannot even remember what it looked like. Possibly it remained with Jonathan Cape? Though the War probably meant that many things got lost-like The Chosen. She never did any other long translation (that was my patch) because she always had so many ideas of her own that she wanted to [bring to completion].

The chosen was published in the summer of 1940, just before the German air raids on London began in early September. Copies that were to be distributed to bookstores around the UK were lost when the publisher's storage facilities were destroyed. At the end of August 2008 Inge learned the good news that a typescript copy (in German) of The Gladiators had been seen in Moscow during a 1993 visit there by Michael Scammell. Her response of 7 November 2008 was to "note with delight that [a typescript existed] - it is strangely satisfying that even the KGB could have some positive effect". The next spring Inge was asked if she had had any personal contact with Koestler in 1938 or over the years since then. Her reply came in an e-mail of 20 May via her niece Antonia Reeve: "You must remember that [in 1938] I was a schoolgirl of 14 or 15, and was never introduced to Koestler. He never met me. Though Edith and I discussed the translation of The Gladiators, and Koestler, I was never 'in' on a conversation with K'.

\subsection{Inge Simon's last years and Edith Simon's legacy}

A year later (23 June 2010) Inge wrote a note of appreciation for receiving a copy of Edith's essay "On Translating Thomas Mann" that had been edited and provided with commentary (Simon, 2009). In passing, Inge remarked that "I have now found more hoards of Edith's letters, some of which had been tidied away-so [I] still hope to answer your questions 
[about Koestler]. The trouble is that although they are all dated and in order of years, the un[published] articles among them are not [...] I am sorry to be such a terrible correspondent, but still hope to improve. The letters are so exciting and so many!" In the spring of 2011 she wrote expressing pleasure that Edith's unpublished essay "In Defense of Historical Fiction" would be published later that same year, edited with full commentary (Simon, 2011).

In the spring of 2012 Antonia Reeve wrote approvingly after receiving an offprint of Edith's essay, and to include Inge's appreciation for seeing it in print after 40 years. Its mention that Edith wrote several film treatments and unproduced plays elicited the comment from Antonia that "Laurence Olivier worked with Edith on one of the plays, but then got distracted by something else". Later that same month (March 2012) Inge wrote that she and her husband Dennis Goodwin had moved from London to Oxford, and also to say thanks again for sending them the publication of Edith's essay. That was her last letter. Inge Goodwin died on 20 September 2014 at the age of 90 . Her children notified friends by letter, and they in turn sent condolences.

Antonia wrote back on 1 December 2014 to note that Inge's husband, at 92, was still alive. She added: "Edith's papers are now in the National Library of Scotland here in Edinburgh, and I believe being gone through as I write (there were 25 crates of material). So if you ever get over here you would be able to explore them. We have also just got hold of Edith's letters, which we hope to scan and then hand over to the National Library as well. If anything to do with Koestler turns up, we will of course let you know".

Edith Simon's correspondence would be well worth a researcher's time and energy, and even if her letters and notes did not add to our knowledge of her in the translation process of The Gladiators, or her relationship in later years with Arthur Koestler, in and of themselves they would illuminate many aspects of her long and creative life. When Koestler's literary agent, A. D. Peters, was in the process of negotiating the sale of Hollywood cinema rights for The Gladiators in the spring of 1957, Edith was asked to sign off on that transaction (in her role as translator) merely as a formality. She requested, and eventually received, an undisclosed amount of money as "additional payment" for the translation work she did. Koestler's correspondence with Peters shows that he was in full agreement that she should be paid the extra money. ${ }^{8}$ No doubt what she did receive in 1938 was just a tiny portion of Koestler's small advance on the book. The planned movie of The Gladiators was never filmed even though a director and cast were announced, but a full screenplay was developed by blacklisted director/writer Abraham Polonsky for United Artists in 1958. This long-lost script was found in 2011 and is due for publication in the near future (MacAdam, 2012, 2018).

Eight years after Simon's second payment for translating The Gladiators, in the "Afterword" to the Danube Edition of that novel, Koestler demonstrated clearly that he did not regret agreeing to her request, nor did he harbor any other grudges from the past: "Born in Budapest and educated in Vienna, I wrote first in Hungarian, then in German, and from 1940 
onward, when I settled in [the UK], in English. The Gladiators belongs to the end of the German period. It was translated by Edith Simon, then a young Art student [in London], who has subsequently become one of the most imaginative practitioners of the art of the historical novel" (Koestler, 1965: 319).

\subsection{Searching for the Jonathan Cape Archive}

Seven years later Koestler wrote to South African-born British novelist, poet, opera librettist, and literary editor William C. F. Plomer (1903-1973) to thank him for his important personal interest in championing The Gladiators and steering the MS toward publication by Jonathan Cape, Ltd. (London) in 1938-1939. Plomer had written to congratulate Koestler on being awarded a CBE in the UK's New Year Honours List. On 7 January 1972 Koestler responded (Koestler, 1972):

\section{Dear Plomer:}

I was moved by your friendly message. I shall never forget that without your Reader's Report on The Gladiators (the year was 1938), [Jonathan] Cape would never have published that first novel, and I wonder whether, without that encouragement, I would have gone on. Probably yes - but it would have been much more difficult.

Thank you again—after thirty-four years. If you feel like meeting again over a drink, let me know.

With best wishes,

Yours, Arthur Koestler.

My hope was that Plomer's "Reader's Report" might survive within the archives of Jonathan Cape, and that initial assessment would constitute a "pre-publication review" of The Gladiators. Correspondence or editors' comments generated by the typescript-to-printedbook process would be an additional bonus. Plomer had been provisionally hired by Cape to evaluate literary manuscripts in April 1937, and was one of several Cape "readers" at the time Koestler opened negotiations for rights to his novel Der Sklavenkrieg (Alexander, 1989: 207213). Since Koestler had a contract in hand "in the beginning of 1938" (see above), and the novel was not yet finished, Cape must have agreed to its publication on the strength of a positive reaction (60,000 copies sold) to Koestler's Spanish testament (Scammell, 2009: 155). Koestler may have provided Plomer with a summary (in English-Plomer could not read German) of the first half of the novel. Such a summary (two pages in German) was found within the Moscow MS; Simon may have translated that abstract for Plomer, giving substance to the book contract with Cape.

Koestler's Cape contract must have stipulated that the novel's publication depended upon a competent English translation. Though Plomer's "Reader's Report" would have been 
submitted after Simon completed the translation, its value as a first critique of The Gladiators made a search for it worthwhile. It is not among Plomer's personal papers at Durham University. Jonathan Cape Ltd. is now part of the Random House Publishing corporate holdings. The online Cape Collection register prompted my contact with the Random House Project Cataloguer (Curator of the Cape Archive at Reading University). I learned that most of the Cape Archive prior to 1960 was discarded when the collection was created. Apart from a few letters to and from Koestler during WW II about other matters, Plomer's evaluation of The Gladiators is gone. Its loss may be compared with how often Richard Dove benefitted from finding similar reader's reports, as well as associated correspondence, in the archives of (e.g.) publishers Allen and Unwin, and Victor Gollancz for that very same period in the 1930s. ${ }^{9}$

Nevertheless it is possible to outline the editorial procedure Plomer followed under Jonathan Cape's direction, and to gain an understanding of what led him to become an advocate for the publication of certain manuscripts, especially fiction:

[He] proved to be a most conscientious reader. His reports, always handwritten in his beautiful script, were thorough, and they usually contained a clear opinion: 'Recommended', 'Not Recommended', or, if he thought the work needed further polishing before publication, 'Worth Consideration'. These recommendations were generally, though not always, followed, and the directors valued Plomer's reports because they were full and consistent enough to enable others to make an independent judgement on the basis of what he had written; even if he advised that a manuscript be rejected, his report allowed others to see whether or not a second opinion should be taken. (Alexander, 1989: 210).

Thanks to his correspondence from precisely this period in the late 1930s, we can gain some very clear insight about Plomer's thinking as he read through stacks of MSS on a weekly basis, some of them submitted poorly typed and badly edited. On 8 October 1938, perhaps as he evaluated Koestler's newly translated The Gladiators, Plomer wrote to his literary colleague Elizabeth Bowen, the Anglo-Irish novelist and short story writer: "An almost unpleasantly wide contact with contemporary fiction has made more clear to me than ever what we all know perfectly well - that the only thing that gives a novel any shape, texture, lustre, or durability is what may bluntly be called poetry, or a poetic sense of the momentousness of what we see and feel, of the drama in trifles and the colour in the drab. Given this sense, the word and the phrase follow [naturally], and the word and the phrase make literature" (Alexander, 1989: 220).

Plomer's "reader's" judgment of The Gladiators, though now unavailable, won the day for Koestler. His reference to "a poetic sense" may well have been inspired by Simon's "poetic" translation of portions of the novel (for one example see section 3.3 below). As 
Koestler realized gratefully 34 years later in his letter to Plomer, his literary career (as distinct from his career as a journalist) began then. Plomer and Koestler probably had no idea that two other similar novels (by Scotsmen) had just been reprinted in the UK and were on sale within London. One was the powerful novel, on the same theme as The Gladiators, by the recently deceased author James Leslie Mitchell (Spartacus, 1937). The other was a reprint of a mid-Victorian romance with exactly the same title as Koestler's book: G. J. WhyteMelville's The Gladiators (1938). Neither sold enough to attract attention. ${ }^{10}$ Koestler's novel, after almost 80 years, has never been out of print.

\section{TRANSLATION ANOMALIES, EDITORIAL MODIFICATIONS, AND LINGUISTIC FEATURES}

\subsection{Translation anomalies in The Gladiators (1939)}

Limitations on the length of this essay, and on the accessibility of the full text of Der Sklavenkrieg before its publication, allow only glimpses of the editorial and translation processes that ultimately produced the first English version of The Gladiators. Apart from the change of title (see below), we now know that the table of contents, and even the quotation that appeared preceding or following the title page also changed. Those are what may be termed "external" modifications. They are not insignificant and thus worth some attention. We can then turn to examination of a few translation issues that illuminate aspects of Koestler's research and/or choice of words, and the way Edith Simon's dealt with them. Readers of this essay may be sure that far greater attention will be given to the translation issues when the full text and commentary are published in 2018. My grateful thanks go to Matthias Wessel for sharing with me the portions of the German original text that are discussed below (see especially sections 3.2 and 3.3).

As noted above, we do not know how the English title The Gladiators came to be substituted for Der Sklavenkrieg. Discovery of the MS shows that Koestler's first choice for a snippet of literary quotation to set the "theme" of this novel was not the short sentence from Silvio Pellico's prison memoir that appears in the Cape first edition (and all subsequent translations). Koestler had originally chosen a quotation from Aristophanes' satirical comedy Ecclesiazusae (Assemblywomen) written in 391 BC. The play is about the creation of a utopia in Athens. The segment he chose is from lines 585-601, splicing two bits of dialogue written for the main female character, Praxagora. The identity of Aristophanes' German translator quoted by Koestler should be easy enough to establish. More important than the change of title or the substitution of one quotation for another are redactions within the table of contents. These are best seen when Koestler's version is placed beside Jonathan Cape's 
editorial modifications (see section 3.3). We may deal first with a few other issues before examining that.

The novel's title Der Sklavenkrieg (The Slave War) was changed during the publication process, but by whom and why is not known. William Plomer, who read the freshly translated MS, might have suggested the change. Until Scammell saw the German original typescript in Moscow in 1993, it was assumed that Die Gladiatoren was in fact the title given to the novel by Koestler. That is certainly what Buckard (2004: 162) believed on the basis of the German back-translation of $1948 .{ }^{11}$ The Koestler papers catalogue entry in Moscow translated the German title accurately as Voina Rabov (Slave war) and lists four subdivisions of the typescript totaling 503 pages. There is circumstantial evidence that the document seen by Wessel in March 2016 is actually the "ribbon copy" which Edith Simon translated and later returned to Koestler. The hand-written note Revidierte Fassung: Original that appears on the first page of the Moscow MS points to such a conclusion. That would explain why a backtranslation into German had to be done a decade later: neither Simon, nor Jonathan Cape, had kept the original typescript on file in London. The translated text of the first Cape edition came to 398 pages.

Koestler undoubtedly did what he could to monitor Edith Simon's translation of The Gladiators, but he had little time in London that summer when he left his German typescript with her and began writing Rubaschow / Darkness at noon. Many British and American reviewers of The Gladiators seemed unaware that it is a translation in spite of Simon's credit as translator on the title page. Those few who did made no complaint of "Germanisms" in her English text. To my knowledge only one book reviewer noticed that a single German word (ironically, Wort) was left untranslated and thus revealed the substrate language (Westington, 1941: 223 referring to the American edition [1939: 96, line \# 31] — corrected in the Danube Edition [1965: 76, line \# 28]). But the same reviewer also mistakenly stated that "American colloquialisms enliven the narrative" (Westington, 1941: 223). There had been no attempt by Macmillan, USA to "Americanize" Simon's British-English translation for Cape when the first American edition was published in July 1939.

In my original summary of Simon's translation process sent to Wessel (December 2015) I drew attention to some apparent anachronisms that could be checked in Moscow to determine if she had mistranslated a word, or if Koestler's German was incorrect for that specific context. Two examples of questionable renderings came to mind: (1) there are duplicate mentions of a multi-storey apartment building's "fire escape" (Koestler, 1965: 9, line \#10; 311, line \#10), and (2) the title of Chapter 5 of Book One, "The Man with the Bullet Head". Both terms appear glaringly anachronistic for a novel set within the Roman Republic of the first century BC.

The first is at the beginning of the narrative in the Prologue to Book One, and occurs again, almost verbatim, at the beginning of the Epilogue. Koestler was fond of parallel scenes in his novels, mirror-images with slight variations that, at least in structure, lend a sense of 
symmetrical opening and closure to the story (e.g. the first and last scenes of his novel Thieves in the night, 1967). In The Gladiators Quintus Apronius, First Scribe of the Market Court in the provincial city of Capua, begins the day (just before dawn) monitoring the return of his aged household slave from purchasing that day's necessities. Both owner and slave live within an "apartment building" (insula) with perhaps 40 residents in similar modest dwellings (Koestler, 1965: 9):

He groans as his toes fish for the sandals on the grimy wooden floor. Once again the sandals stand the wrong way, toes facing the bed; the young day's first offence; how many more are to come? He shuffles along to the window, looks down into the courtyard, a deep shaft surrounded by five storeys. A bony old woman comes climbing up the fire escape: Pomponia, his housekeeper and only slave, brings breakfast and the pail of hot water [...] [She prepares Apronius' breakfast and sees that he is properly dressed, then] [...] In worried dignity he descends the fire escape [...]. [emphasis, in bold, mine].

Ancient apartment buildings did not have what we know as fire escapes constructed only for that purpose, but there were exterior staircases connecting interior courtyards to a flat roof directly above, and then additional outer stairs from that roof to one above it. Few buildings in ancient Capua, where the first scene is set, would be more than two storeys in height: we have the structural remains at the nearby sites of Herculaneum and Pompeii (inter alia) as evidence of that (McKay, 1975). ${ }^{12}$ It may be that Simon was confused about that "outside stairway" concept and opted for "fire escape". Koestler prided himself for researching even trivial aspects of Roman culture: dress, manners, décor, and architecture (Koestler, 1965: 318-319). It seemed of interest to learn from the original text if he had confused Simon on this point, and then he (and others) missed the anachronism when proofreading The Gladiators.

The second example is less conceptual and more contextual. Baldness of older men was just as common throughout antiquity as it is now, so I wondered why Koestler would choose a word (such as Kugelkopf?) for a descriptive term that did not exist in languages until gunpowder and bullets were invented a millennium later. "Bullet-head" as a physical characteristic of an ancient Essene philosopher in that chapter is very odd indeed to an English-language reader. Did Koestler write glatzköpfig-or kahlköpfig-or even rundköpfig-Mann instead? Was this an example of "Koestlerian imagery" that Simon just was not familiar with, and dealt with it as best she could? Roman ballistae hurled stone or metal "balls" at enemy fortifications or armies, and that globular shape may be the image Koestler intended for the aged Essene's bald head. ${ }^{13}$ Did Simon somehow misunderstand that? If so, even the book's editors did not catch this second anachronism and raise the question before printing the text. 
The original German typescript supplies the answer to both questions, and I am indebted to Matthias Wessel for providing this textual confirmation in advance of full publication of Der Sklavenkrieg. He clarified what Koestler wrote about ancient "fire escapes" in an e-mail to me of 30 March 2016:

Based on your notes on the translation issues, I also checked the matter of "bullet head" and "fire escape". As for "fire escape", it is really there, all over the original MS. It is either Feuerleiter or Feuerstiege, which is quite irritating given the fact that it clearly seems to be the only stairs available to get into or out of Apronius' flat. So this is definitely an anachronism (and a kind of logical flaw) by Koestler himself. Possibly his knowledge of Roman architecture was not as well founded as Koestler thought it was. For example, in the "Prolog" [to Book I] he writes about Apronius: Er schluerft zum Fenster, blickt in den Hof hinab, in den fuenf Stockwerke tiefen Schacht des Mietshauses. This sharply contradicts what you write in your notes, that "Few buildings [in a Roman provincial city in Italy] would be more than two storeys in height”. [emphases, in bold, mine]

In this instance Koestler was the one at fault, not realizing that Feuerleiter was infelicitous (though not technically inaccurate) in describing a feature of an ancient building. Simon's translation was accurate, and she could not be expected to know that an architectural concept term such as German or English "fire escape" was not in use until the nineteenth century. Wessel went on to say in that e-mail:

As for "bullet head", it is Der Kugelköpfige in the [chapter title of the] original MS, quite close to the [1948] retranslation [of the Chapter 5 title] Der Mann mit dem Kugelkopf. If I remember correctly, I already told you that from the point of view of a German native speaker, there is nothing wrong with [describing] the character like that, and that it only becomes out-of-place in the English translation, because of the narrow meaning of "bullet". [Wessel had already noted in an e-mail to me of 7 Dec. 2015 that "The back translation I have at hand (a cheap reprint of the 1960 Scherz edition) uses Kugelkopf'].

Book One Chapter 5 is not the only place in The Gladiators that Koestler uses the image of "baldness" to characterize an individual. In the preceding Chapter 4 ("The Crater") we follow the misadventures, leading to disaster, experienced by the Roman commander sent against the growing slave army on Mt. Vesuvius. Like Spartacus and other key characters in the novel, the praetor Clodius Glaber is an historical figure found in the ancient sources. As the Roman forces advance, the troops satirize their commander with a "Hymn to the Pate", a song in recognition of his bald head. There is a sly cleverness to this scene on Koestler's part because he was aware that the praetor's cognomen glaber is one of several words in Latin that denote "baldness". Depending on which German term Koestler used in this instance may 
be instructive as to whether he sought to distinguish between the bald Roman commander, and the aged bald Essene slave who joined the insurrection. In this particular instance the solution must wait until the full MS is made available. We need not wait to see how Simon coped with translating some other technical terms, and then a more lyrical passage, of Koestler's prose: see the following sections.

\subsection{Editorial modifications to the table of contents}

We now can identify small and large editorial changes made to Koestler's table of contents for Der Sklavenkrieg. These are best seen when Koestler's version is placed beside the table of contents for The Gladiators; the significant modifications are shown underlined. A brief commentary on these changes follows below:

\begin{tabular}{|l|l|}
\hline \multicolumn{1}{|c|}{ Der Sklavenkrieg } & \multicolumn{1}{c|}{ The Gladiators } \\
\hline Prolog: Die Delphine & Prologue: The Dolphins \\
\hline Erstes Buch: Der Aufbruch & Book One: Rise \\
\hline 1. Das Gasthaus & 1. The Inn by the Appian Way \\
\hline 2. Die Insel [sic] & 2. The Bandits \\
\hline 3. Die Räuber [sic] & 3. The Island \\
\hline 4. Der Krater & 4. The Crater \\
\hline 5. Der Kugelköfige [sic] & 5. The Man with the Bullet-head \\
\hline Intermezzo: Die Delphine & \\
\hline Zweites Buch : Das Gesetz des Umwegs & Book Two: The Law of Detours \\
\hline & Interlude: The Dolphins \\
\hline 1. Die Versammlung & 1. The Meeting \\
\hline 2. Untergang der Stadt Nola & 2. Destruction of the Town Nola \\
\hline 3. Der gerade Weg & 3. Straight Road \\
\hline 4. Die Wandlungen der Stadt Capua & 4. The Tides of Capua \\
\hline 5. Der Umweg & 5. Detour \\
\hline 6. Die Erlebnisse des Advokaten Fulvius & 6. The Adventures of Fulvius the Lawyer \\
\hline 7. Die Chronik des Advokaten Fulvius & 7. The Chronicle of Fulvius the Lawyer \\
\hline Drittes Buch: Der Sonnenstaat & Book Three: The Sun State \\
\hline 1. Hegio, ein Bürger der Stadt Thurium & 1. Hegio, a Citizen of Thurium the City \\
\hline 2. Der Einzug & 2. The Entry \\
\hline 3. Gründung der Sklavenstadt & 3. The New Law \\
\hline 4. Das Netz & 4. The Net \\
\hline 5. Der Neuling & 5. The New-Comer \\
\hline 6. Die grosse Weltpolitik & 6. World Politics \\
\hline 7. Das Heimweh & 7. The Longing \\
\hline 8. Die roten Aederchen & 8. The Little Red Veins \\
\hline
\end{tabular}

(C) Servicio de Publicaciones. Universidad de Murcia. All rights reserved. IJES, vol. 17 (1), 2017, pp. 37-59 Print ISSN: 1578-7044; Online ISSN: 1989-6131 


\begin{tabular}{|l|l|}
\hline 9. Untergang der Stadt Metapont & 9. Destruction of the Town Metapontum \\
\hline 10. Die höheren Gründe & 10. The Lofty Reasons \\
\hline 11. Die Entscheidung & 11. The Turning Point \\
\hline 12. Das Ende der Sonnenstadt & 12. The End of the Sun City \\
\hline 13. Die Heimkehr des verlorenen Sohnes & 13. The Desire to Remain \\
\hline Intermezzo: Die Delphine & \\
\hline Viertes Buch: Der Untergang & Book Four: Decline \\
\hline & Interlude: The Dolphins \\
\hline 1. Die Schlacht am Garganus & 1. The Battle by the Garganus \\
\hline 2. Talfahrt & 2. Downhill Journey \\
\hline 3. Die Grabsteine & 3. The Tombstones \\
\hline 4. Die Begegnung & 4. The Interview \\
\hline 5. Die Schlacht am Silarus & 5. The Battle by the Silarus \\
\hline 6. Die Kreuze & 6. The Crosses \\
\hline Epilog: Die Delphine & Epilogue: The Dolphins \\
\hline
\end{tabular}

Re-arrangement of some chapters, the placement of two of the "Interludes", nuanced translations of some chapter titles, and the replacement of the title of Book Three Chapter 13 are the main changes. The reasoning behind these changes, especially the decision to replace the clearly biblical title "Die Heimkehr des verlorenen Sohnes" ("The Return of the Prodigal Son") with the diffuse and secular phrase "The Desire to Remain", is not yet clear. Koestler's title "Der Kugelköfige" ("The Ball-headed") for Book One Chapter 5 is odd indeed: "Der Kugelkopf" or "Der kugelköfige Mann" would be expected instead. Koestler's Book One title Aufbruch ("Awakening") might well have been borrowed from the title of Kafka's 1930 short story of that name. Aufbruch has a poetic parallel of sorts in the Book Four title Untergang ("Downfall"). Both appear to be deliberate literary choices. Thus it is very odd that Simon translated them as "Rise" and "Decline", respectfully, as if the alternate terms Aufstieg and Niedergang were Koestler's choices for opening and closing "units" of Der Sklavenkrieg.

Worth noting also is the title for Book Four Chapter 4: Koestler's "Die Begegnung" (“The Encounter") becomes Simon's “The Interview". Neither accurately denotes the face-toface (and failed) "negotiations" Koestler envisioned between Spartacus and Crassus prior to the final battle of the protracted Slave War. Wessel informs me that when the full text of Der Sklavenkrieg has been published it will reveal that within individual chapters, blocks of narrative were rearranged or, in some cases, eliminated. Wessel estimated (in an e-mail to me of 30 March 2016) that the translated novel is shorter than the original by perhaps 25 pages of the $500+$ pages typescript, a "cut" of about $5 \%$. We may assume that most, if not all, of the editorial changes were made after Simon's typescript translation (not saved by her or by Cape) was submitted to Cape's editorial team in the autumn of 1938. Simon's personal 
papers, now being sorted and catalogued at the National Library of Scotland in Edinburgh, may contain correspondence regarding her translation and the editorial process during the winter of 1938-1939 that led to publication of The Gladiators in London (March 1939).

\subsection{Linguistic features of translation: Magic, divination, tragic foreshadowing}

\section{Excerpt and translation of a selection from Der Sklavenkrieg}

(Koestler's text in italics, my literal translation in unmodified font, and Simon's translation in bold)

Below is a section of Koestler's novel that sets the scene on the eve of the final battle (71 BC) between the Slave Army led by Spartacus and the Roman forces commanded by Crassus. I have broken it into four units of equal length, in a few places omitting narrative that detracts from the main theme: how magic and divination surface as powerful forces in human events at times of crisis. Koestler's later interest in coincidence and parapsychology is foreshadowed here, as the full tragedy of the protracted slave insurrection is lent an air of foreboding and doom. The latter aspect - that all revolutions fail because their means and ends are so fatally divergent - is characteristically Koestlerian. Readers should be aware that I am neither a professional translator nor a literary savant. Nevertheless I have always had a great respect for finely wrought historical fiction, as did Koestler and Simon (on this see especially Simon, 2009 and 2011). Simon's abilities as a literary translator of skill and poetic grace (at only age 21 ) are very evident here:

1. Die Nacht schritt fort, und Spartacus lag auf seiner Matte. Auch er hatte in dieser Nacht nicht allein sein wollen, neben ihm atmete die Frau, schmal und dunkel, fast noch ein Kind [...] [several events are then described in detail that illustrate her special powers] [...] Ähnliche Begebnisse kamen öfter vor, und bestärkten ihren Ruf als Seherin des Verborgenen und Künderin der noch nicht eingetroffenen Dinge.

The night progressed, and Spartacus lay on his pallet. He also did not want to be alone that night; next to him breathed the woman, slim and dark, almost a child [...] Similar [uncanny] incidents happened more often, and strengthened her reputation as a seer of the Hidden, and the harbinger of things that had not yet occurred.

The night progressed, and Spartacus lay on his rug. He had not wanted to be alone this last night either; beside him breathed the woman, dark and slender, little more than a child [...] Similar [uncanny] incidents occurred quite often, and helped to strengthen her reputation as a seer of the hidden and obscure, and a herald of things as yet concealed by the future. 
2. Denn früher schon hatte sie zeitweilig in diesem Ruf gestanden, als ehemalige Priesterin des thrakischen Bacchos, die in das Geheimnis des orphischen Kultes eingeweiht war; hatte sie nicht dem Spartacus selbst, als dieser noch als gemeiner Zirkus-fechter lebte, die furchtbare Macht verkündet, die ihm zuteilwerden sollte? Er hatte damals auf der Erde gelegen und geschlafen, die Frau aber sah zu, wie eine Schlange herankroch und sich um sein Haupt wand, ohne ihm Schaden zuzufügen; da hatte sie alles Kommende gewusst.

Because earlier she had come under this reputation as a former priestess of Thracian Bacchus, who was privy to the secret of the Orphic cult; had she not proclaimed to Spartacus himself, when he was yet a common circus-fighter, the terrible power that would be given to him? He had then been sleeping on the ground, but the woman watched as a snake crawled and wrapped itself around his head, without harming him; in that way she had known everything that was coming.

For she had gained this reputation earlier on, being a former priestess of Bacchos of Thrace, initiate of the Orphic cult; had she not announced to Spartacus the terrible power in store for him, when he was a mere common circus-gladiator? He had been lying on the floor, asleep, but the woman watched a serpent sneaking towards him and coiling round his head without harming him in any way; and thus she had known of all that was to be.

3. Lange hatte der Spartacus sich nicht um sie gekümmert; und die Leute sagten, er meide sie aus Scheu vor der Berührung mit den dunklen und andeutungsvollen Kräften, die sie in sich trug. Es wurde gesagt, er wolle von diesen Mächten des Zwielichtigen und Verborgenen nichts mehr wissen [...] Doch als die Sonnenstadt [i.e. the slave utopia] in Trümmer gefallen war, nahm er sie wieder zu sich; und nun, da die Nacht fortschritt, atmete sie neben ihm auf der Matte, schmal, mädchenhaft zart, und fremd noch in der Umarmung.

For long Spartacus had not taken care of her; and people said he shunned her for fear of making contact with the dark and powerful forces that she bore within herself. It was said that he wanted nothing more to do with these powers of shade and secrecy $[\ldots]$ but as the Sun City had fallen into ruins, he took her back to himself; and now that the night progressed, she breathed beside him on the pallet, slender, girlishly delicate, and strange in the embrace.

Spartacus had been neglecting her for a long time; and people said he shunned her to avoid meeting and touching the dark and allusive powers she bore within her. It was said he wanted nothing to do with these powers of twilight and obscurity [...] But when the Sun City crumpled in ruins, he took her with him again; and now as the night progressed, she breathed beside him on the rug, slim, girlish and frail, and alien in the embrace. 
4. Früher hatte er sie wegen ihrer dunklen Fähigkeiten gemieden; nun aber rief er sie gerade um dieser willen [...] und auch er wusste, das es die letzte Nacht war, und hätte gerne gehört, was nachher kam, wenn die Sonne nicht mehr aufging und der Atem stille-[sic]stand. Die finsteren Gätter Thraciens [sic] hatte er längst vergessen und den alten Essäer [his moral mentor] aus Scham nicht zu fragen gewagt; auch schien ihm, dass man im Schoss der Frau der Antwort näher war, alsbei allen Priestern und Weisen dieser Welt.

Previously he had shunned her because of her dark skills; but now he called for her just because of these things [...] and he also knew that it was the last night, and would have liked to hear what came afterward, when the sun no longer rose and breath stood still. The sinister Gods of Thrace he had long forgotten, and was afraid to ask the old Essene due to shame; it also seemed to him the answer was closer through a woman's touch than through all the priests and wise men of this world.

Before, he had shunned her for the sake of her eery powers; but now he wanted her because of them [...] and he too knew that this night was his last, and he would have liked to hear about what happened afterwards, when the sun rose no more and breath was still. He had long forgotten the illboding gods of Thrace, and he had been ashamed to ask the aged Essene; and also it seemed to him that a woman's embrace might bring you closer to the answer than the company of all the priests and magi of this world.

[German text: Der Sklavenkrieg typescript, pages 478-480; Edith Simon's translation in Koestler, 1965: 301-302].

These specific passages were chosen to determine the accuracy and efficacy of Simon's translation of text that is evocative of a cultural concept (in this case magic or divination or the interpretation of portents), rather than narratives elsewhere in the novel that are largely or even completely descriptive (armies on the move, battles, the layout of cities) or focus on dialogues and/or debates (philosophical discussions, interviews) or are prosaic and even clerical in nature (journal entries, military dispatches).

In segment \#1 the cluster of specific nouns in one phrase (Seherin des Verborgenen und Künderin) is not accidental, especially when contrasted with the physical description of the woman as schmal und dunkel, fast noch ein Kind. Simon brings out this contrast, perhaps in part because she fit that description. Koestler used the Greek biographer Plutarch (Life of Crassus 8:3) for the famous anecdote (segment \# 2) about the serpent. Again in segment \# 3 we find the same contrast of magical powers (diesen Mächten des Zwielichtigen und Verborgenen) in direct contrast with physical attributes (schmal, mädchenhaft zart). Simon's "eery" (in segment \# 4) is the British spelling of American "eerie"; in that same segment the double typo Gätter Thraciens needs correcting to Götter Thrakiens. 
If the quality of Simon's translation was not clear to Koestler in 1938, he would have realized it after WW II when the novel was back-translated into German as Die Gladiatoren, and still later acknowledged it in print in his autobiography The invisible writing, and again in the Danube Edition of The Gladiators.

\section{CONCLUSION: A NEW ASSESSMENT OF ARTHUR KOESTLER AS NOVELIST}

Discovery of the German originals of Arthur Koestler's first two published novels offers not just a chance to assess the author as a writer of German fiction, but also to judge the quality of the first English translations of The Gladiators and Darkness at noon. It is the second of those two considerations that is central to this essay, which is focused on The Gladiators. Until now very little was known about the process by which Der Sklavenkrieg became The Gladiators. This was so not only because the MS of the original could not be consulted, but also because so little was known about the role of the novel's translator, Edith Simon, during the time she worked for Koestler. ${ }^{14}$

Thanks to assistance from Simon's family through correspondence, and permission from Matthias Wessel to read and reproduce portions of the newly discovered typescript in Moscow, it is possible now to begin an overdue evaluation of this complex and carefully crafted historical novel. Full publication of the German original with commentary is expected by 2018 , and along with that will be a new English translation. The latter will of course offer detailed comparisons with Simon's original, which until now was the basis of translations into all other languages.

In parallel with that project will be the publication of the German original of Darkness at noon in tandem with a new English translation. We may anticipate renewed and important studies of Koestler as novelist on the basis of the two works of fiction for which he is best known. This essay suggests several directions that future evaluations can go, but it also provides a broader context for the process of preparing The Gladiators for its 1939 publication.

\section{ACKNOWLEDGEMENTS}

My thanks to both anonymous readers of this essay, whose comments and criticisms have improved its style and content. I would also like to thank Scammell for introducing Wessel via personal communications, and Wessel for providing the obscure reference to Fond k 613. I also acknowledge permission granted to publish the Unpublished letter to William Plomer. 


\section{NOTES}

1 These works were originally published in 1939, 1940, and 1943, respectively. Unless otherwise specified, reference will be made to the Danube editions, dating to 1965, 1973 and 1966.

2 Koestler's first novel, written in 1934 but not published until 2013, was entitled Die Erlebnisse des Genossen Piepvogel und seiner Freunde in der Emigration (The Adventures of Comrade Cheepy-bird and his Friends in Exile. Matthias Wessel provided this information.

3 https://www.uni-kassel.de/uni/internationales/english-version/university/about-us/news/article/ long-missing-original-manuscript-of-the-novel-darkness-at-noon-by-koestler-has-beenfound.html. Wessel's dissertation general subject area is German Literature of the twentieth century.

4 Koestler scholars have not given Edith Simon much attention, but the recovery of the original MS of The Gladiators will now change that. The best brief summary of her multi-faceted career is the obituary that appeared in one of Scotland's premier newspapers: http://www.scotsman.com/ news/obituaries/edith-simon-1-544516. More detail is available in Goodwin (2005).

5 Cape needed a replacement "reader" for new book manuscripts when their senior reader since 1921, Edward Garnett, died suddenly and unexpectedly in early 1937. William Plomer, who had reviewed books for, and also published books with, Jonathan Cape, was hired for a six-month probationary period. He stayed with Cape for the next thirty-six years (Alexander, 1989: 207).

6 For a full account of Edith Simon's career as a prolific author and artist highly regarded in both fields, see the commentary to two of her posthumously published essays (Simon, 2009, 2011) the commemorative volume in her honor, Moderation be damned! (Goodwin, Sutherland \& Reeve, 2005), as well as the Introduction to a commemorative essay on Koestler and the importance of his novel The Gladiators as literary Rezeptionsgeschichte (MacAdam, 2006).

7 Isherwood's semi-autobiographical satirical novel, published in 1945, is largely forgotten today. Its premise is filmmaking in England during the 1930s. Prater Violet is the movie's eponymous title, named for the famous Wurstel Prater Amusement Park in Vienna (where the iconic Ferris Wheel scene of Graham Greene's Cold War thriller The third man [1949] was filmed). Violet refers to the film's heroine, who sold flowers in the Park. The movie's director is a fictionalized self-exiled Austrian Jew: "The name, the voice, the features were inessential. I knew that face. It was the face of a political situation, an epoch. The face of Central Europe" (Isherwood, 1978: 24). Richard Dove correctly characterized that novel and its protagonist " $[\ldots]$ as representative of a literary and political period" (2000: 13).

8 The A. D. Peters Agency correspondence and business papers from the 1920s through 1960 are currently archived in the Harry Ransom Center at the University of Texas (Austin). Papers dated from after 1960 are archived in the Boston University Library.

9 Two examples may illustrate this. Dove (2000: 66) recounts that Neumann tried to get Allen and Unwin to accept a trilogy of novellas (all in German) for publication: "The comments of Unwin's reader, on this occasion Edward Crankshaw, serve to illustrate the cultural obstacles confronting the foreign (and particularly the German) writer in adapting to the English market". In another case, Neumann's translator, Edwin Muir, exchanged letters with Neumann, and Muir then wrote to the publisher (Victor Gollancz) about translation problems. That correspondence is on file in the Gollancz Archive (Dove, 2000: 67 and note \# 77). The Cape Archive might still have such documents but for the arbitrary and unconscionable decision by someone to remove and destroy them.

10 Nor did The Gladiators at first (in spite of generally favorable reviews in the UK and the USA) because of WW II. In part due to that initial positive reception, but more because of enthusiastic response to Darkness at noon (originally published in 1940), Cape and Macmillan issued several reprints $(1947,1949,1950)$ of The Gladiators on both side of the Atlantic. Translations began in 1948. It appeared in paperback in 1954 and had not been out of print since then; the latest English reprint was 2011.

11 Three of the five major twentieth century novels about the Third Servile War simply used the name Spartacus as their title: von Uxkull (1920), Mitchell (1937), and Fast (1951). The fourth chose Arena (Ghnassia, 1969). For those as well as earlier (nineteenth century) novels, and a 
half-dozen motion picture depictions of the Spartacus Revolt over the past century, see MacAdam (2015).

12 See Chapters II and IV in general, and a visual reconstruction of an insula (McKay, 1975: 93, Fig. 31). McKay notes that "Tenants [of individual apartments] must have prepared their daily meals on portable stoves and braziers, which also provided rudimentary heating in winter" (1975: 94).

13 Ballistae (inscribed and uninscribed) used by both sides in military clashes during The Slave War of 73-71 BC are referenced and commented on in Shaw (2001, Documents \# 48 and \# 61).

14 While this article was in press I learned that a small cache of correspondence, mostly letters from Arthur Koestler to Edith Simon, are among the personal papers of Edith Simon now being archived at the National Library of Scotland in Edinburgh. The letters to Simon from Koestler (all but two in German) date from late 1936 to late 1940, and all concern her ongoing translation of his novel Der Sklavenkrieg. There are also two letters from London publishers, one to Koestler and one to Simon. I hope to publish this collection, with commentary, in the near future.

\section{REFERENCES}

Alexander, P. F. (1989). William Plomer: A biography. New York, NY / Oxford: Oxford University Press.

Anonymous (1951). RGVA /former Special Archive records [The Central State Special Archive of the USSR, Moscow]. Fond k 613, op. 1, "Koestler, Arthur (1905-1983), writer, journalist (1937-1940)". (NB: k stands for kollektsiya (collection) — it was added to all Fond numbers of the previous Special Archive).

Buckard, C. (2004). Arthur Koestler: Ein Extremes Leben (1905-1983). München: C.H. Beck.

Dove, R. (2000). Journey of no return: Five German-speaking literary exiles in Britain, 1933-1945. London: Libris.

Fast, H. (1951). Spartacus. New York, NY: Blue Heron Press.

Ghnassia, M. (1969). Arena: A novel of Spartacus and Crassus. New York, NY: The Viking Press.

Goodwin, I. (2005). Edith Simon. In I. Goodwin, G. Sutherland \& A. Reeve (Eds.), Edith Simon: Moderation be damned! (pp. 3-17). Edinburgh: Privately published.

Goodwin, I., Sutherland, G. \& Reeve, A. (Eds.). (2005). Edith Simon: Moderation be damned! Edinburgh: Privately published.

Isherwood, C. (1978). Prater violet. New York, NY: Avon Books.

Koestler, A. (1939). The Gladiators. New York, NY: Macmillan.

Koestler, A. (1965). The Gladiators. Danube Edition. New York, NY: Macmillan.

Koestler, A. (1966). Arrival and departure. Danube Edition. New York, NY: Macmillan.

Koestler, A. (1967). Thieves in the night. Danube Edition. New York, NY: Macmillan.

Koestler, A. (1969). The invisible writing. Danube Edition. New York, NY: Macmillan.

Koestler, A. (1972). Unpublished letter to William Plomer, 7 January. Item \# 117 in the William Plomer Collection, Durham University Library (UK).

Koestler, A. (1973). Darkness at noon. Danube Edition. New York, NY: Macmillan.

Koestler, A. (2013). Die Erlebnisse des Genossen Piepvogel und seiner Freunde in der Emigration. Zurich: Europa-Verlag.

MacAdam, H. I. (2006). Arthur Koestler's The Gladiators and Hellenistic history. Scripta Judaica Cracoviensia, 4, 69-92.

MacAdam, H. I. (2012). Spartacus Redivivus: Hollywood's blacklist revisited. Left History, 16(2), $55-71$.

MacAdam, H. I. (2015). Dramatizing Roman history: Spartacus in fiction \& film. Roman Archaeology Group Magazine, 10(2), 1-5.

MacAdam, H. I. (2018, in preparation). The Gladiators: An epic film failure in blacklist Hollywood.

McKay, A. G. (1975). Houses, villas, and palaces in the Roman world (Aspects of Greek and Roman Life). Ithaca, NY: Cornell University Press.

(C) Servicio de Publicaciones. Universidad de Murcia. All rights reserved. IJES, vol. 17 (1), 2017, pp. 37-59 Print ISSN: 1578-7044; Online ISSN: 1989-6131 
Mitchell, J. L. (1937). Spartacus. (2nd ed.). London: Jarrolds.

Scammell, M. (2009). Arthur Koestler: The literary and political Odyssey of a twentieth-century skeptic. New York, NY: Random House.

Scammell, M. (2016, April 7). A different Darkness at noon. New York review of books. Retrieved 1 November, 2016 from http://www.nybooks.com/articles/2016/04/07/a-different-darkness-atnoon/.

Shaw, B. D. (2001). Spartacus and the slave wars: A brief history with documents. Bedford Series in History and Culture. Boston, MA / New York, NY: Bedford / St. Martin's.

Simon, E. (2009). On translating Thomas Mann: An unpublished essay by Edith Simon (H. I. MacAdam, Ed., Intro. and commentary). Scripta Judaica Cracoviensia, 7, 111-142.

Simon, E. (2011). In defense of historical fiction: An unpublished essay by Edith Simon (H. I. MacAdam, Ed., Intro. and commentary). Left History, 15(2), 43-61.

The Scotsman. (2003, January 30). Edith Simon. Retrieved 1 November, 2016 from http://www.scotsman.com/news/obituaries/edith-simon-1-544516.

Universität Kassel. (2015, August 10). Long missing original manuscript of the novel "Darkness at Noon" by Koestler has been found. Retrieved 1 November, 2016 from https://www.unikassel.de/uni/internationales/english-version/university/about-us/news/article/long-missingoriginal-manuscript-of-the-novel-darkness-at-noon-by-koestler-has-been-found.html.

Von Uxkull, W. K. H. A. (1920). Spartacus: Ein Roman aus der römischen Gladiatorenzeit. Dresden: Lehmannsche Verlag.

Wessel, M. (2014). "Becoming anglicized"? The increasing importance of English characters in the exile novels of Robert Neumann and Arthur Koestler. Moravian Journal of Literature and Film, 5(2), 41-50.

Wessel, M. (2017, forthcoming). Arthur Koestler's novels written in exile. Doctoral Dissertation, University of Kassel, Germany.

Westington, M. M. (1941). Review of Arthur Koestler, Edith Simon (1939). The Gladiators. Macmillan. The classical weekly, 34(19), 222-223.

Whyte-Melville, G. J. (1938). The Gladiators: A tale of Rome and Judaea. London: J. M. Dent \& Co. 